\title{
Designing a Village Museum Ecologically: Reuse of Historic School Building
}

\author{
By Özlem Karakul*
}

The number of the village museums has highly increased in recent years parallel to the increase in the care of the ways of life, intangible cultural heritage of societies. Designing village museums necessitates to understand the tangible and intangible characteristics of village accurately, specifically, both the architectural language of traditional buildings and the cultural practices of people. This study aims to present a process of designing a village museum in a historical building in the village as a common design problem between the disciplines of interior design and conservation. The reuse of the historic building primarily necessitates to deal with both the structural system and the values of the building which constitute the reasons for conservation of the buildings and the architectural significance of the building besides the natural, economic and cultural characteristics of its context. The reuse of historic buildings necessitates its adaptation to the program of the new function by certain interventions, like, new extensions. This study presents a specific framework for reusing of a historic school building in Botsa Village in Konya as a village museum developed within an interior design studio. The design framework is mainly based on discovering the ecological principles of local architecture and oriented to the needs of villagers emerging within cultural and touristic developments.

\section{Introduction}

The role of the education in the conservation of cultural heritage has highly been emphasized in the international documents prepared by $\mathrm{UNESCO}^{1}$ in recent years. From this respect, it needs to prepare specific interdisciplinary courses conforming to the educational aims and processes of the different departments in the school's curriculum. In the departments of architecture and interior design of universities, throughout the studio projects, studying the elements of cultural heritage provides students first to understand the elements of heritage, and its cultural context, and then, to raise their awareness on the conservation of both tangible and intangible cultural heritage.

This study shares an interior design studio experience developed from three discussions on designing "village museum", reusing historic buildings and ecological architecture. Therefore, first, a literature search on the historical development of museum understandings, the reuse of historic buildings and ecological architecture will be discussed and after that, the process and results of the studio experience will be clarified in detail.

\footnotetext{
*Associate Professor, Selçuk University, Turkey.

1. Unesco, The Convention for the Safeguarding of the Intangible Cultural Heritage (Paris, October 2003).
} 


\section{Historical Overview of Understandings of Museum}

From the beginning, museums have generally focused on displaying the various elements of tangible heritage. ${ }^{2}$ After the 2003 UNESCO Safeguarding Intangible Cultural Heritage Convention, museums have been accepted as one of the tools for safeguarding intangible heritage on the national level for the implementation of the convention. The understanding of emotions, meanings and values with or without physical embodiment is also crucial for the safeguarding of both tangible and intangible heritage. ${ }^{3}$ In this respect, "musealization" approaches need to consider the values and meanings of the people attributed to buildings while displaying intangible cultural heritage ${ }^{4}$.

Even if museums conflict with living intangible cultural heritage, especially for the conservation of the disappearing elements of intangible heritage, they are indispensable for collecting, conserving and displaying the material traces of the past. ${ }^{5}$ Determining the conflicts between traditional museum practices and living culture, Alivizatou tries to suggest new functions and roles for museums by developing the concept of "post-museum." Especially, the new understanding of museums has responsibility for presenting tangible properties with its cultural expressions or developing new methods to conserve and display intangible cultural heritage. Accordingly, "video and sound recordings of cultural expressions and practices"7 can be used in museums to display the processes of intangible cultural heritage.

As emphasized in the UNESCO 2004 Expert meeting, ${ }^{8}$ museums are a part of their context, either, buildings, gardens, parks, neighborhoods, villages, so, they need to reflect both the physical and cultural qualities of these multilayered contexts in their spatial organization and display techniques. Thereby, museums can also be accepted as a space for gathering living heritage and bearers in every context. For displaying and safeguarding living heritage, local museums have a more crucial role than national museums. From this respect, village museums as local museums need to reflect the soul of their contexts which is constituted by both physical characteristics and intangible values. In addition to this, museums have also gained an educational role to teach local inhabitants in different subjects and local crafts to increase local economic growth and create employment in the village.

2. M. L. Stefano, "Safeguarding Intangible Heritage: Five Key Obstacles Facing Museums of the North East of England," International Journal of Intangible Heritage 4, Jan. (2009): 112.

3. Ibid, 113.

4. Ö. Karakul, "Designing the Museum of Turkey's Intangible Cultural Heritage: A Studio Experience of Interior Architectural Design,” Milli Folklor-International and Quarterly Journal of Cultural Studies 30, no. 120 (2018): 140-157.

5. M. Alivizatou, Museums and Intangible Heritage: The Dynamics of an "Unconventional" Relationship (London: UCL Institute of Archaeology, 2006), 17, 47.

6. Ibid, 48.

7. Ibid, 51.

8. Unesco, The Roles of Museums in Safeguarding Intangible Cultural Heritage. UNESCO Convention, October 2003. Position Paper for the Expert Meeting, 2004. 


\section{Current Understandings of Reuse of Historic Buildings and Use of Ecological Approaches}

The theoretical approaches of conservationists and international and national documents have shared common ground on the necessity of reusing the historic buildings constructed for the different lifestyles and cultures to serve new and contemporary functions through their restoration processes. ${ }^{9}$ The management of change is accepted as one of the aims of the conservation of cultural heritage, defined as "the action taken to prevent decay and manage change dynamically" by Feilden. ${ }^{10}$ Given this emphasis, it can be stated that re-using existing historic buildings, which have become out- of use in time due to a great variety of reasons, needs to create a new life in harmony with the changing life conditions. According to the contemporary conservation approaches, which have developed after the 1964 Venice Charter all over the world, reusing is considered as the only way to conserve and sustain old buildings ${ }^{11}$.

"Adaptation" and "adaptive reuse" are the new terms used for expressing the reuse of the historic buildings. "Adaptation", defined as one of the degrees of intervention for conservation purposes in the Icomos New Zealand Charter includes the interventions from" maintaining its continuing use" or, from "a proposed change of use." "The aims of adaptive reuse projects are mainly to conserve the historic buildings; meaning to safeguard their qualities and values, their material substances and ensure their integrity for future generations. ${ }^{13}$ Thus, the adaptive reuse of historic buildings needs to have minimal impact on the heritage significance of the building, mainly, the integrity of spatial and architectural characteristics.

The aims of adaptive reuse projects are mainly to conserve the historic buildings; meaning to safeguard their qualities and values, their material substances and ensure their integrity for future generations. ${ }^{14}$ Thus, the adaptive reuse of historic buildings needs to have minimal impact on the heritage significance of the building, mainly, the integrity of spatial and architectural characteristics.

The function of "museum", aiming to conserve and exhibit the objects included, is the one not overloading to historic buildings. ${ }^{15}$ The adaptive reuse of historic buildings as museums is a complex subject in architectural conservation

9. D. Kuban, Tarihi Çevre Korumanın Mimarlık Boyutu: Kuram Ve Uygulama (İstanbul: Yapı-Endüstri Merkezi Yayınları, 2000); L. Zakar and K. K. Eyüpgiller, Mimari Restorasyon Koruma Teknik ve Yöntemleri (İstanbul: Ömür Matbaacılık, 2015); E. Madran and N. Özgönül, Kültürel ve Doğal Değerlerin Korunması (Mimarlar Odası, 2005), 158.

10. B. Feilden, Conservation of Historic Buildings (London; Boston: Butterworth Scientific, 2003), 3 .

11 Karakul, "Designing the Museum of Turkey's Intangible Cultural Heritage: A Studio Experience of Interior Architectural Design," 2018.

12. Icomos New Zealand, Charter for the Conservation of Places of Cultural Heritage Value. 2010. https://bit.ly/2LqJNBa.

13. B. M. Feilden and J. Jokilehto, Management Guidelines for World Cultural Heritage Sites (Rome: ICCROM, 1993).

14. Ibid.

15. Kuban, Tarihi Çevre Korumanın Mimarlık Boyutu: Kuram Ve Uygulama, 2000. 
necessitating to develop conservation measures for both buildings and the included objects. As Madran and Özgönül states "the historic buildings to be converted into museum should also be considered like as an object" to be exhibited, besides the collections included. ${ }^{16}$

Through the reuse process, to use ecological approaches inspiring from traditional architecture helps to achieve harmony with the local architectural language of historic building and environment. In ecological architecture, the terms 'tradition' and 'technology' especially come forward to understand the relationship between natural environment and traditional building technologies. ${ }^{17}$ Today, the main objective of the ecological design approaches is "to achieve acceptable indoor environmental conditions for occupants with the least expenditure in energy and materials, replacing non-renewable energy sources with renewable ones and doing away with environmentally unfriendly processes and materials." building examples, traditional architecture includes specific lessons to be learned by architects and students to design new buildings. Traditional architecture is a valuable resource to discover the ecological principles with regard to its inclusion of the variety of the nature friendly designs, the usage of local materials and the creative building methods to be inspired by architects.

Turkish traditional architecture is specifically accepted as a successful model for new buildings in terms of "representing our cultural values and the reflection of their erection period honestly." been the sources of inspiration for some of the well-known architects, like Le Corbusier, to develop the principles of Modernism. ${ }^{20}$ Bektaş investigates Turkish traditional architecture to highlight certain common principles to be considered for sustainability as (1) suitability to life, nature and environmental conditions, (2) realism and rationalism, (3) solution from interior to exterior, (4) harmony between interior and exterior, (5) frugality, (6) the principle of easiness in construction methods, (7) selection and use of local materials nearby environment, (8) elasticity. ${ }^{21}$ When reconsidered these principles within the scope of ecological architecture, it can be seen that they completely coincide with the main objective of ecological approaches mentioned above on a large scale.

Arising from the new museum understandings and reuse approaches, this article aims to share an interior design studio experience, carried out in the Department of Interior Architecture in Selçuk University, focusing on a village museum design in Botsa to discuss specific ways to concretize the various elements of local cultural heritage through the reuse process of a historic school

16. Madran and Özgönül, Kültürel ve Doğal Değerlerin Korunmasl, 2005.

17. Karakul, Discovering Ecological Principles of Traditional Architecture: Cappadocia Region. Sustainable Housing 2016-International Conference on Sustainable Housing Planning, Management and Usability, 16-18 November. Porto, Portekiz, 2016.

18. W. Weber and S. Yannas (eds.) Lessons from Vernacular Architecture (Great Britain: Routledge, 2014), 2.

19. C. Bektaş, Koruma Onarım Conservation Restoration (İstanbul: Y.E.M. Yayın, 1992), 5.

20. E. Kortan, Le Corbusier Gözüyle Türk Mimarlık ve Sehirciligi (Ankara: ORTA DOĞU TEKNIKK ÜNIVERSITESİ, 1983), 41-75.

21. Bektaş, Türk Evi (İstanbul: Yapı Kredi Yayınları, 1996), 23. 
building; and to use ecological design approaches discovered from local building tradition raising the students' awareness of their conservation.

\section{A Design Problem of Botsa Village Museum}

The studio project carried out in the spring semester of the 2015-2016 academic year addressed to solve the problem of designing a village museum for Botsa Village to develop various ways for displaying the cultural heritage of the village; besides solving the various social and touristic needs of villagers. Students were expected to develop their design approach by considering both the architectural features of museum buildings and Botsa's cultural heritage besides developing an awareness of contemporary conservation approaches on historic buildings. The methodology of this studio work was mainly based on an interdisciplinary approach necessitating to understand both the elements of intangible cultural heritage of the village from a folklorist's point of view, the elements of tangible cultural heritage from an architects' point of view and the historic building from a conservation architect's point of view. Apart from the prevailing ethnographic approaches on the traditional village museum designs, the village museums to be designed are intended to orient the economic and cultural life of the villagers and to create employment within Botsa.

\section{Historic School Building in Botsa}

Botsa (Güneydere) is a village located $45 \mathrm{~km}$ far from Meram in Konya. Botsa is one of the settlements in the region of Hatunsaray, which is known as Antique Lystra. $^{22}$ The history of the settlement dates back to Iron Age 2000 B.C. according to the findings obtained from Mula and Hatunsaray Mound. ${ }^{23}$ Within the village, there are a great number of remains of buildings from the periods of Hellenistic, Roman and Christianity. ${ }^{24}$ There are a great number of carved-out buildings which were especially used for the religious activities through Christianity period (Figure 3). The Region is characterized by its peculiar earth formation, which is the product of a very long geological process. The geological formation of the region has been very suitable for construction in terms of carving out easily and as building stones getting hard after exposed to air. Botsa Village was proclaimed as an urban conservation site and III. Degree urban, archeological and natural conservation site in $1994 .^{25}$

22. T. Bozkurt, "Konya-Hatunsaray (Lystra) ve Cevresindeki Cami ve Mescitler," Ankara Üniversitesi Dil ve Tarih-Coğrafya Fakültesi Dergisi 55, Jan. (2015): 3.

23. H. Bahar, "Konya Araştırmaları III; Lykaonia| Konya Merkez Bölgesi," Selçuk University Journal of Faculty of Letters (Fen-Edebiyat Fakültesi Edebiyat Dergisi) 12 (1998): 197-206; Bahar, Konya-Hatunsaray Yerleşmesinde Erken Demir Çă̆l Çanak Çömleği, Hatunsaray Yerleşmesi'nde Erken Demir Çă̆l'na Geçişs (Institute of Turkish Ancient Age Sciences, 2003); İ. M. Mimiroğlu, Kilistra-Gökyurt, Meram Municipality. Konya, 2014.

24. Bozkurt, "Konya-Hatunsaray (Lystra) ve Cevresindeki Cami ve Mescitler," (2015): 4.

25. See. The decision of Regional Conservation Council of Cultural properties of Konya numbered 2084 in 05.10.1994. 
The peculiarity of the topographical structure and earth formation is a dominant feature among the environmental factors affecting the formation of the settlement characteristics and building typologies, as well as the climate. The earth formation on which the settlement is laid down, is mainly formed by a stream and tuff rocks surrounding Botsa Village. Buildings on the slopes on the north side of stream are placed in an adjacent way and not closing the views of others through the valley (Figure 1).

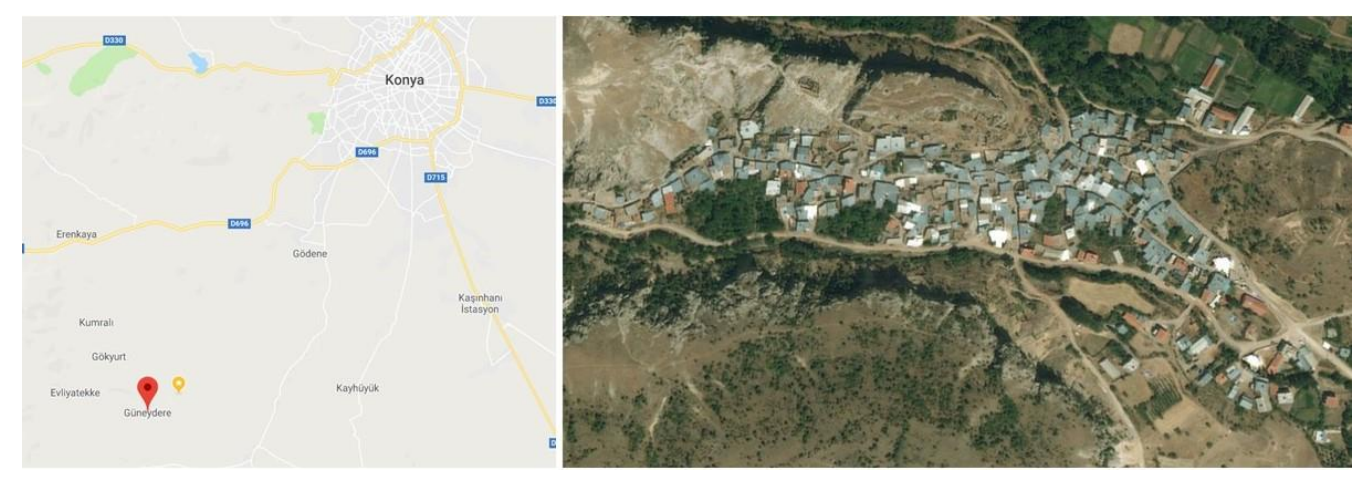

Figure 1. Map Showing Location of Botsa (left) and an Aerial Photo of the Village (right) Source: Google Map (left) and Apple Maps (right).

The traditional architecture of Botsa Village includes both public/ commonly used buildings like carved-out religious buildings, mosque, masjids, village rooms, village school building and fountains and traditional dwellings. ${ }^{26}$ The traditional buildings of Botsa Village, both public buildings and traditional dwellings, have been constructed by using stone masonry technique with timber bonds, as seen in the traditional architecture of Konya. ${ }^{27}$ The traditional architecture of the village exhibits an authentic stone and timber building tradition with their local characteristics (Figure 2).

The old village school, constructed by using stone masonry technique in 1936 according to the information obtained from the villagers; ${ }^{28}$ has various conservation problems due to being unused for long time (Figure 4). The building, which is located on the main street going through the village, has a great garden behind, along the stream.

26. Karakul, "Bozkırda Yeşeren Köy| Botsa,” Yapı Dergisi, Yapı Endüstri Merkezi 433 (2017): 154-158.

27. H. Karpuz, Osmanlı'da Konut Mimarisi Konya Örneği (İstanbul: Eyüp Sultan Sempozyumu III, 2000); Karpuz, "Konya'da Halk Mimarisi,” Erdem 38, no. 10 (2002); O. N. Dülgerler and M. Sözen, Samples from Konya Houses (ODTÜ Mimarlık Fakültesi Dergisi, 1979), 5, 1.

28. Informant: Lokman Saraç. 

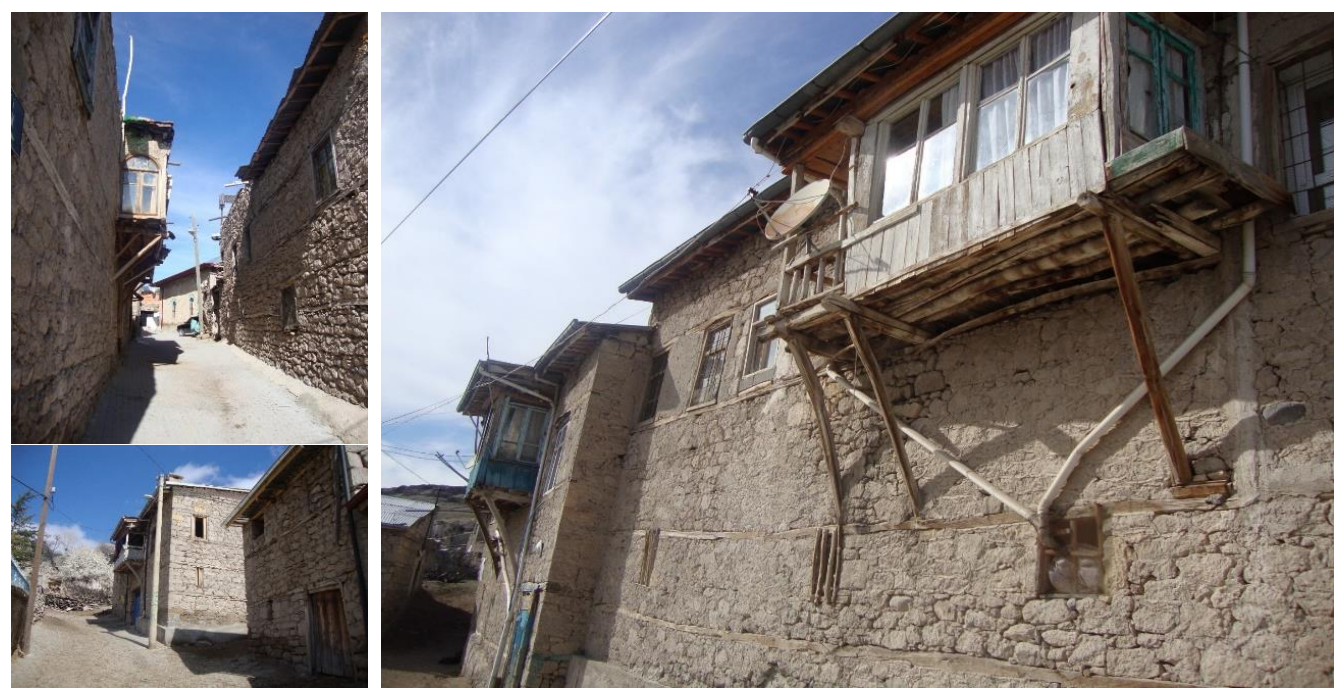

Figure 2. Street Characteristics and Dwellings

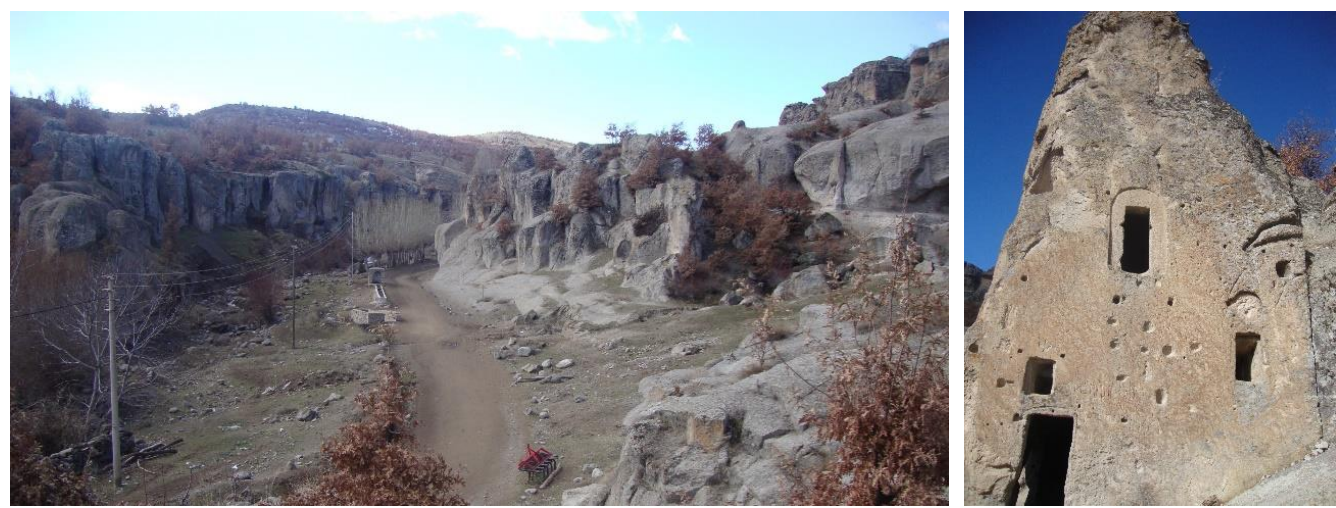

Figure 3. Tuff Rocks and Carved-out Buildings

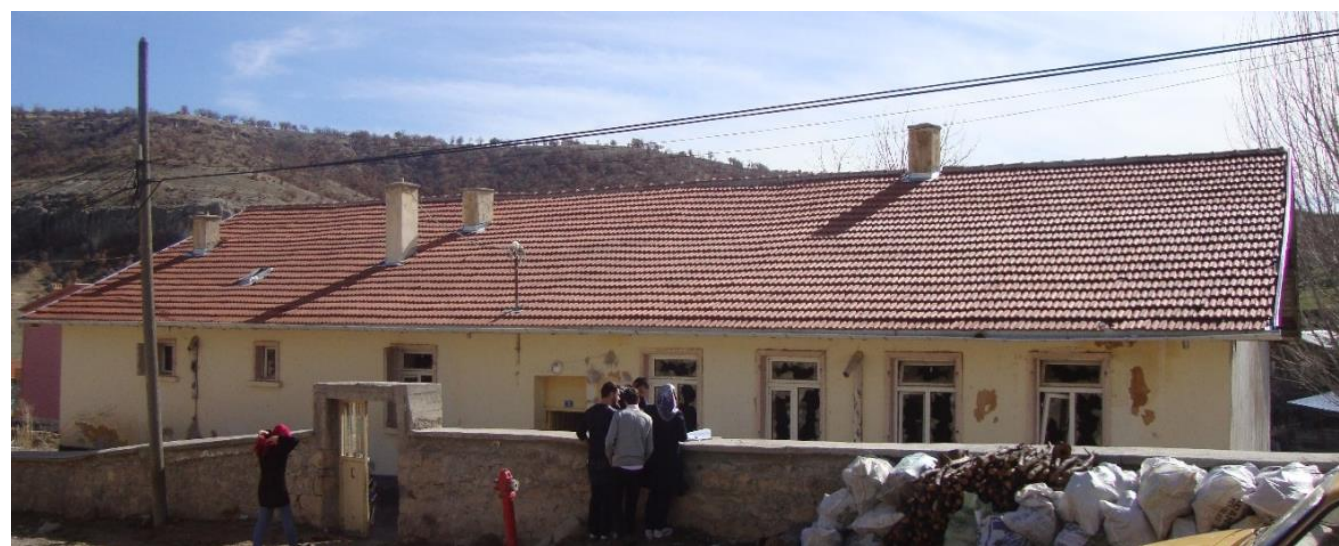

Figure 4. Historic School Building

\section{Projects}

Throughout the studio project, students were asked to solve a design problem of interior design of the given building, The Historic School Building of Botsa. 
The studio project mainly addressed to solve the problem of the design of a village museum to understand how the design process affected over the consciousness of students about the representation of the physical and cultural characteristics of village over spatial features and about the conservation of the building in the projects.

The studio discussions mainly focused on discovering and exhibiting the spatial aspects of cultural heritage particular to Botsa Village; and construing an ecological architectural approach to provide the continuity of the local building culture. Considering this aspect, students are also expected to develop specific design approaches to provide a continuity in both living and building culture through discovering specific ecological principles embedded in traditional architecture. In this scope, it is intended to develop specific spatial and architectural approaches to test the ecological architectural principles, like green roofs, naturefriendly construction; and the contemporary uses of local building materials.

There were four phases of the studio for the students: (1) preparation of the inventory of the building and site survey (2) literature research on the reuse of historic buildings, museum designs, ecological architecture and the traditional architecture of Botsa Village (3) preparation of the program of village museum considering exhibition halls: one of which is designed for displaying Botsa's cultural heritage, specifically, cultural practices, traditions and traditional craftsmanship, and another for contemporary art exhibitions like painting, sculpture, to be arranged periodically, a multi-purpose hall for the conference and film showing, library and workshops for both local crafts and contemporary arts for providing employment (4) the development of an original conceptual approach and the designing process.

At the beginning of the studio, the students firstly surveyed and measured the school building studied; and prepared its architectural drawings to be used for the design process. Throughout this inventory work, students were expected to understand the values of the building within its context.

The design process of the studio project started with a literature search on the reuse of historic buildings, museum designs, ecological architecture and the traditional architecture of Botsa Village. By making an evaluation of the data obtained from literature search, students formed their specific conceptual approaches including their point of view in reuse, museum design, ecological design and the values of Botsa Village to outline their design of village museum. Throughout the reuse process of historic school building into the museum, the design of new mass additions and underground spaces could also be developed with the individual interpretations of the students.

Through the design stages, the students were encouraged to determine their own principles on the use of local materials and ecological approaches for educating and stimulating villagers and to develop a nature-friendly architectural language. The students were expected to develop a conceptual approach about how to integrate the values of Botsa Village into the interior design of the museum building, to prepare the building programs and the requirement lists and functional relations, to make the spatial analyses of the building by caring the architectural values. 
Reconsidering information obtained from literature research and site survey, the students tried:

- To be in harmony with the historic building: creation of a closer dialogue between new design additions and the architectural integrity of the old building, specifically, building elements, spatial characteristics, architectural elements.

- To organize the programmatic requirements: exhibition spaces considering the variety of the local differences and workshops as the special training spaces for educating and transmitting local crafts.

- To utilize interactive and digital tools for revitalization the elements of local cultural practices and craftsmanship within the museum.

- To realize an atmosphere of village museum in the building without disruption of the spatial and authentic character of the historic building

- To discover the ecological sustainable principles of local traditional architecture and use in a contemporary way.

Within the scope of this paper, seven student projects were handled with regard to their specific design approaches and their handling way of the elements of the cultural heritage of Botsa, the requirements of village museum and ecological design in detail.

\section{First Design Work}

The main idea orienting the design process of the first design work ${ }^{29}$ is to conserve and sustain the cultural values of the village besides creating employment in the village (Figure 5). The main aim of the first project is to bring nature, either in raw or processed way, into the interior; and to make the building one of the works being exhibited. To bring nature into the space, wide openings were used to enjoy the panoramic scenery of the rocky mountains and the rock-cut buildings over them; and; the colors of the nature, like green, orange, white and brown were used on the surfaces of the spaces and furniture. The designer was also used a great number of solar panels on the new roof designed to provide the electricity and warm water for the building. The main design approach is to use the main building for exhibiting Botsa culture and the underground floor newly designed for the contemporary art activities, conferences and workshops. The new mass and space additions to the main building which are designed in a transparent way, includes a circulation space containing a stair going down to the underground spaces on the basement floor and a semi-open terrace overlooking the stream. All new additions were constructed by using local materials, like timber, in a modern and simple architectural style to achieve to be harmony with the architectural elements of the building. The designer uses the main building to exhibit a great variety of the elements of living and building culture of Botsa village and to perform the traditional crafts, like pottery and weaving carpets with the skilled

29. The project was designed Ahmet Kemal Ünsaçan. 
hands of local craftsmen within the historic building without destroying the architectural significance of the building. On the main building, there were also certain spaces designed for teaching pottery for the guests. On the basement floor, which was formed by carving out from the rock under the main building, a multipurpose hall, an exhibition hall and workshops, a café and foyer spaces and a library and reading space were arranged in a modern architectural style. The workshops within the periodical exhibition areas were designed for the guest artists.


Figure 5. First Design Work 


\section{Second Design Work}

The main design approach of the second design work $^{30}$ is to use the main building for exhibiting Botsa's cultural values and for teaching local crafts, pottery and weaving carpet; and the underground floor newly designed for the contemporary art activities, conferences and contemporary art workshops, library (Figure 6). The new mass and space additions to the main building were constructed by the laminated timber structure and glass coverings in a transparent way to provide harmony with the historic buildings and its context. On the main floor, within the new building attached to the main building includes an entrance space with a stair going down to the exhibition and foyer space on the basement floor; a café and an exhibition on agriculture and animal husbandry. On the basement floor carved-out from the rock layer under the main building, all spaces were designed in a modern and simple architectural style not to contradict with the historical building architecture and its nearby environment.

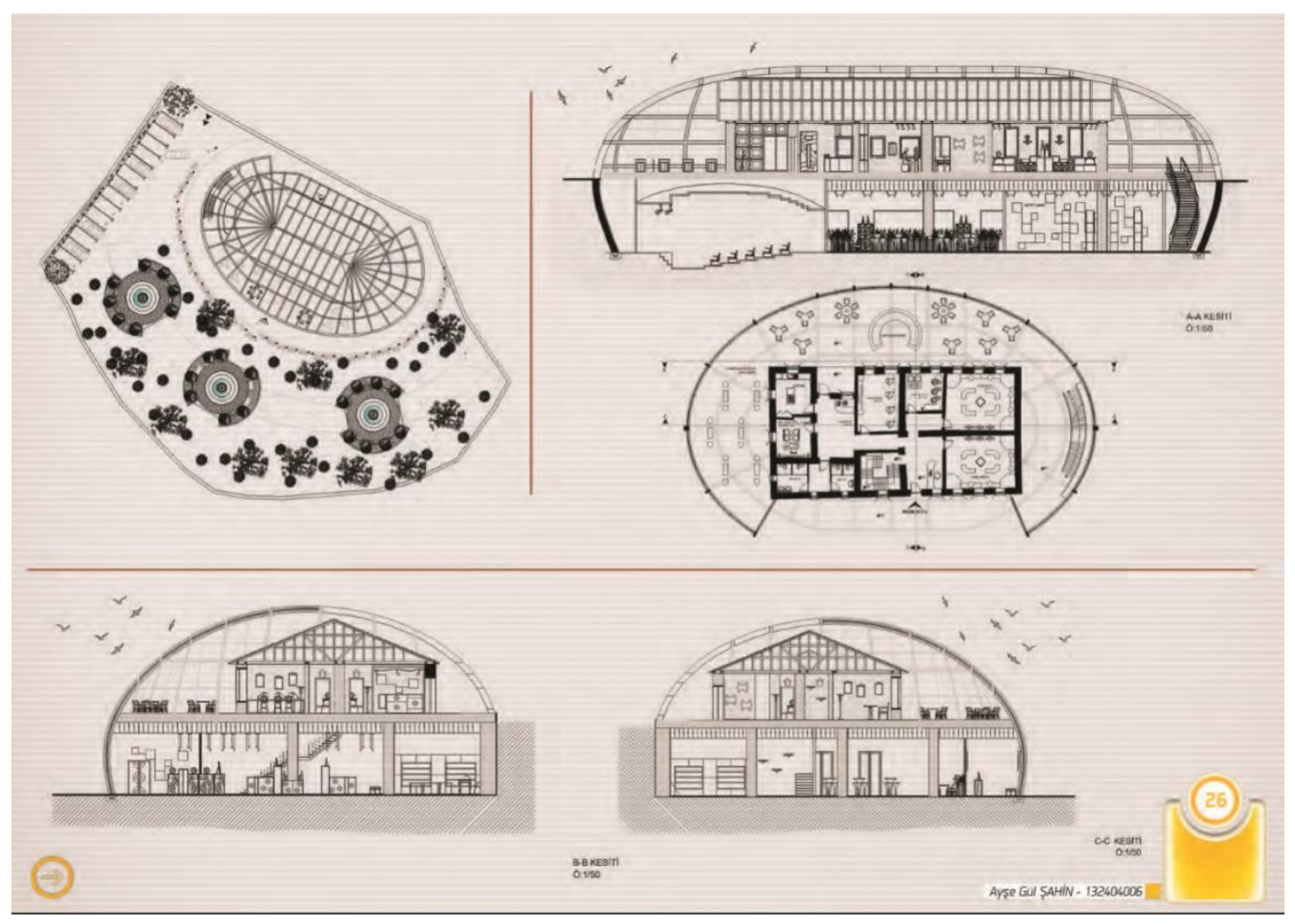

30. The project was designed by Ayşegül Şahin. 


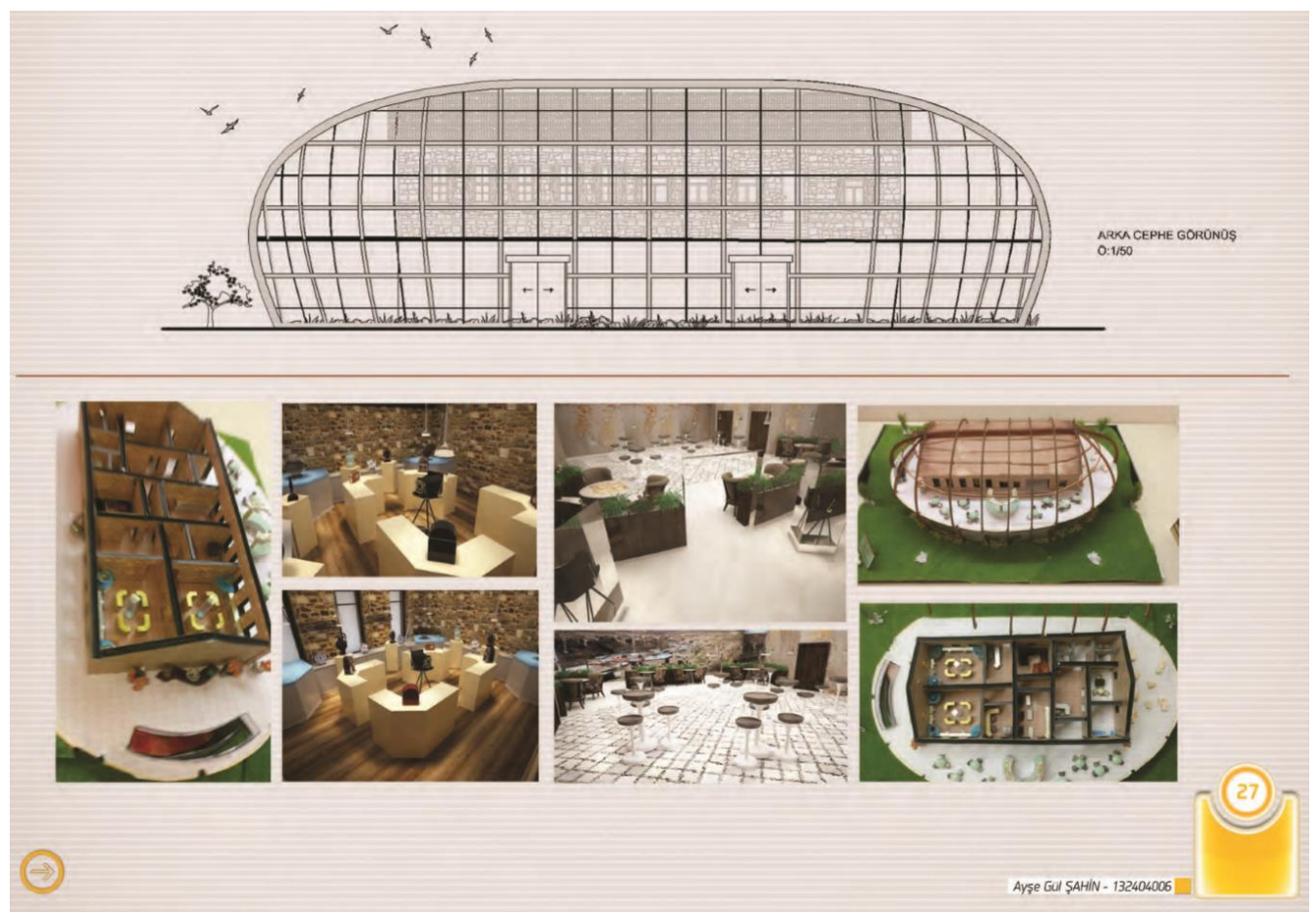

Figure 6. Second Design Work

\section{Third Design Work}

The main idea orienting the design process of the third design work ${ }^{31}$ is to use the principles of ecological and accessible architecture. The project used the main building for a permanent and a digital exhibition about Botsa and two workshop exhibition room and a sales unit designed in an open planning understanding (Figure 7). On the carved-out basement floor, there are two workshops for local crafts, specificially, weaving carpets and pottery, a large foyer, a multipurpose hall for the conferences and performances and a library, a cafe and administrative units. The vertical green surface panels assembled into the steel structure, used to surround the terrace spaces, also provide sun control for the main building. In interior spaces of the main building, massive wood, a local building material, was used as the main material of the architectural elements, like shelfs and tables, in a contemporary technique and language to provide harmony with the historic building. Green and brown colors were especially preferred on the interior surfaces and architectural elements.

31. The project was designed by Meltem Dolmac1. 

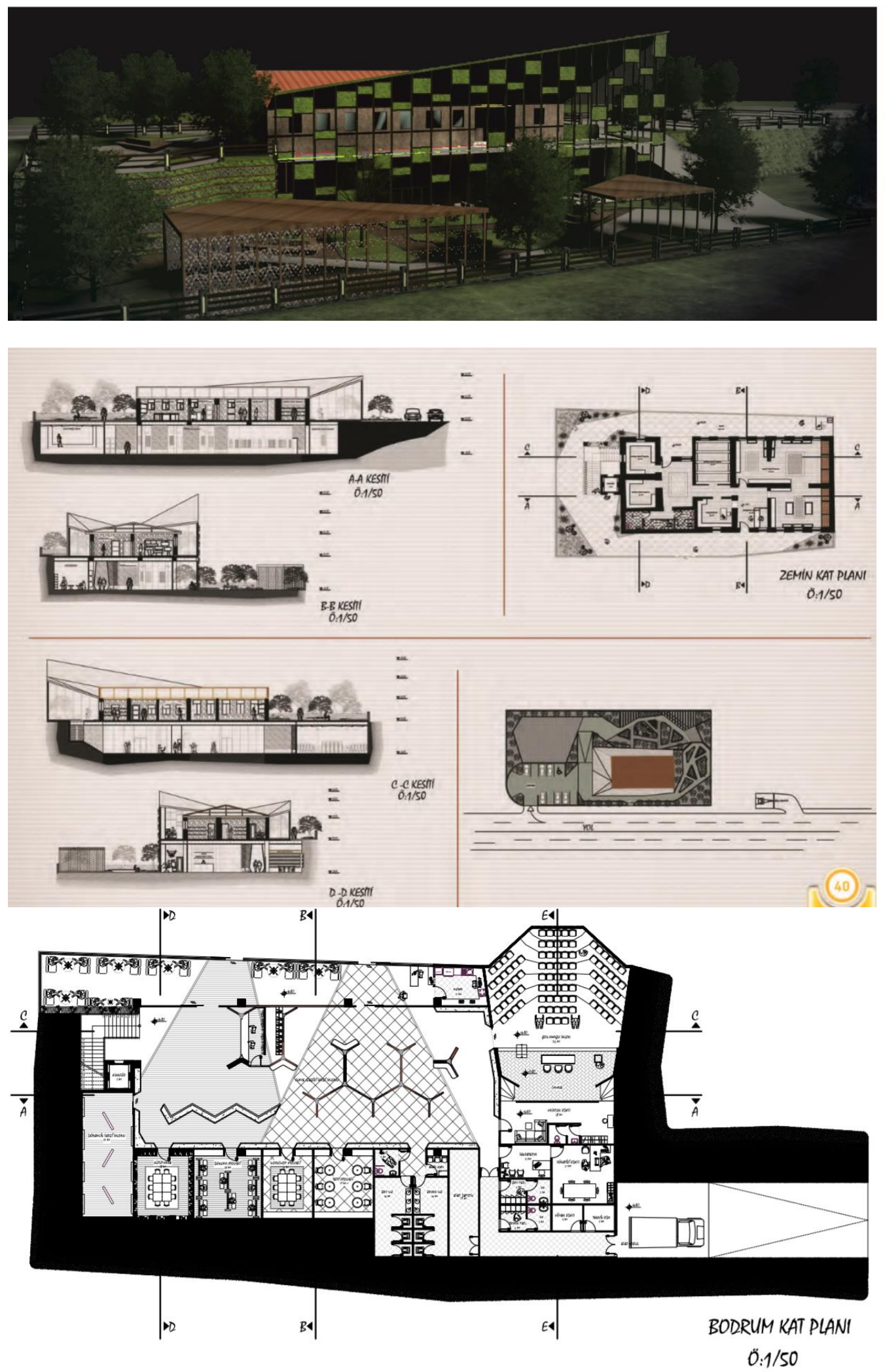

Figure 7. Third Design Work 


\section{Fourth Design Work}

The main design idea of the fourth project ${ }^{32}$ is not to make any new mass addition to the main building not to disturb its massive characteristics, only to make a new large basement floor carved out from underground rock formation (Figure 8). The design approach was based on using the main building for exhibitions on Botsa's cultural values and hand crafts and workshops of local crafts; and, the underground floor newly designed for the contemporary art activities, conferences and contemporary art workshops and library. The terrace roof over the basement floor is used as an open café looking into the impressive scenery of the village composed of stream and tuff rocks. The project also tries to sustain local building technology in a modern construction to provide harmony with the surrounding traditional context.

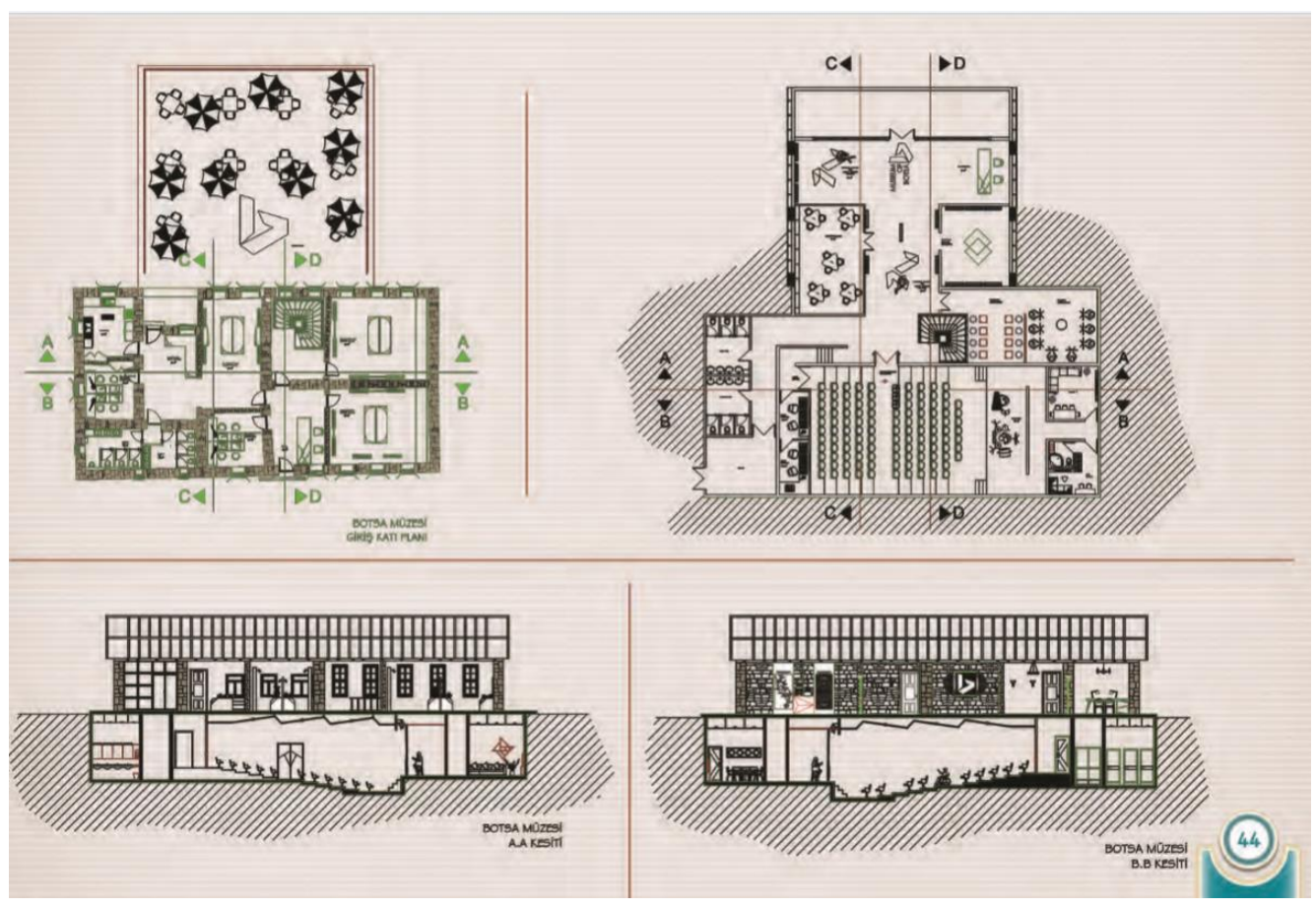

32. Project was designed by Semih Arüv. 


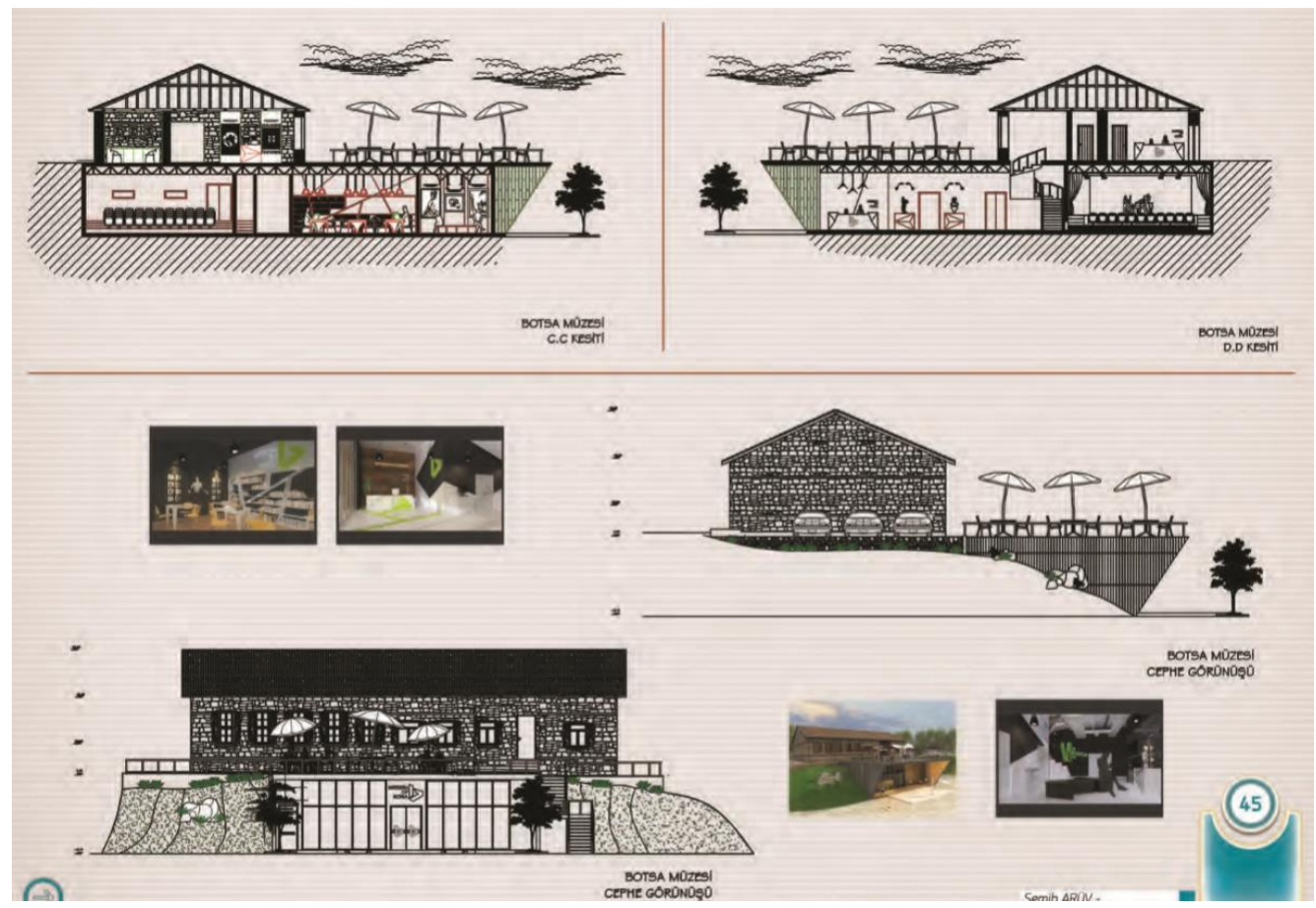

Figure 8. Fourth Design Work

\section{Fifth Design Work}

The main design idea of the fifth project ${ }^{33}$ is to make a new mass addition to the back side of the main building, designed transparently without disturbing the visual perception of the historic building and of the scenery composed of stream and tuff rocks (Figure 9). Adopting the ecological approaches, the roof of new additional building was completely covered with the solar panels to meet the requirement of the electricity and warm water of the building. The designer used local building materials, like wood and stone besides modern building materials not to destroy the contextual architectural language. The design approach was to use the main building for exhibitions on Botsa's cultural values and hand crafts and workshops of local crafts and a digital exhibition space using digital media related to local cultural practices; and, the basement floor newly designed for the contemporary art activities, conferences and contemporary art workshops and a café. Within the new additional building, there is a café having both semi-open and closed spaces looking into a magnificent scenery. The designer also reinterpreted the form of a local plant, called üzerlik otu, which has been used for making amulet for long years in nearby environment, and stylized for using its new interpretations over the interior surfaces and furniture design. The designer used both local building materials, like, wood, glass, and the new ones, like, steel, rope in harmony in the interior of the building. On the basement floor, the carvingout method, extensively used in local building technology, was used for making a

33. Project was designed by Esra Altıparmak. 
variety of niches in different geometries, especially, semi-circular, in a contemporary language.
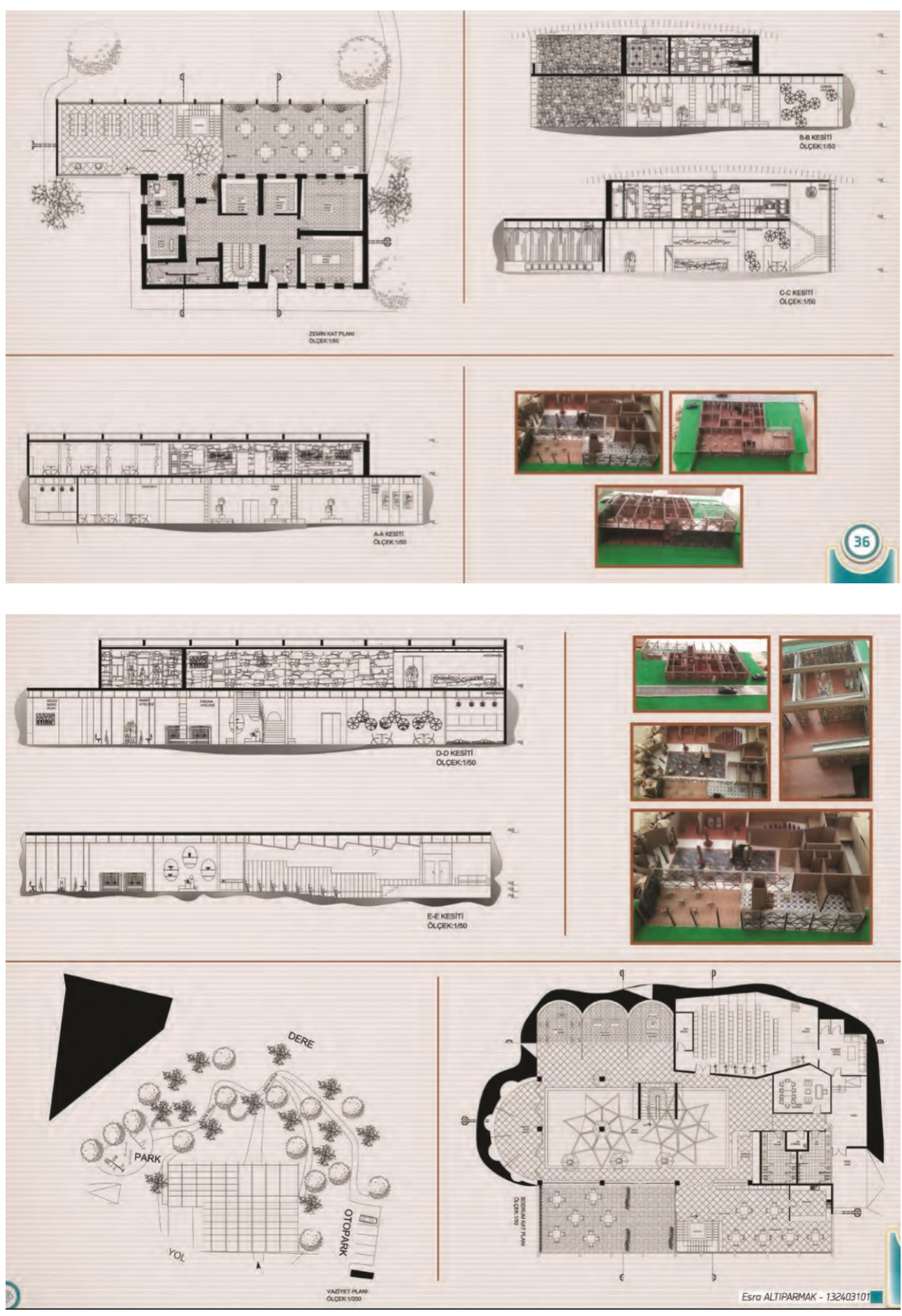

Figure 9. Fifth Design Work 


\section{Sixth Design Work}

The main idea orienting the design process of the sixth design work ${ }^{34}$ is to use the principles of sustainable architecture (Figure 10). Arising from the idea that sustainable architecture aims to create a self-sufficient society in the long term, using contextual possibilities in design process, like local materials, climate, technology and natural resources, the designer used a large green roof over the new mass addition to the historic building and the green surfaces and natural materials on interior wall surfaces and architectural elements. Within the main building, there are different spaces for exhibition on the cultural values of Botsa Village, two workshops on weaving carpet and pottery and a library, and a café on the green open area including a public stair going down to foyer on basement floor between the main building and new addition in which there are a café and an exhibition. On the basement floor constructed by carving, there are two workshops on painting for both adults and children, a library and a multi-purpose hall, and a large exhibition area connected to the foyer.

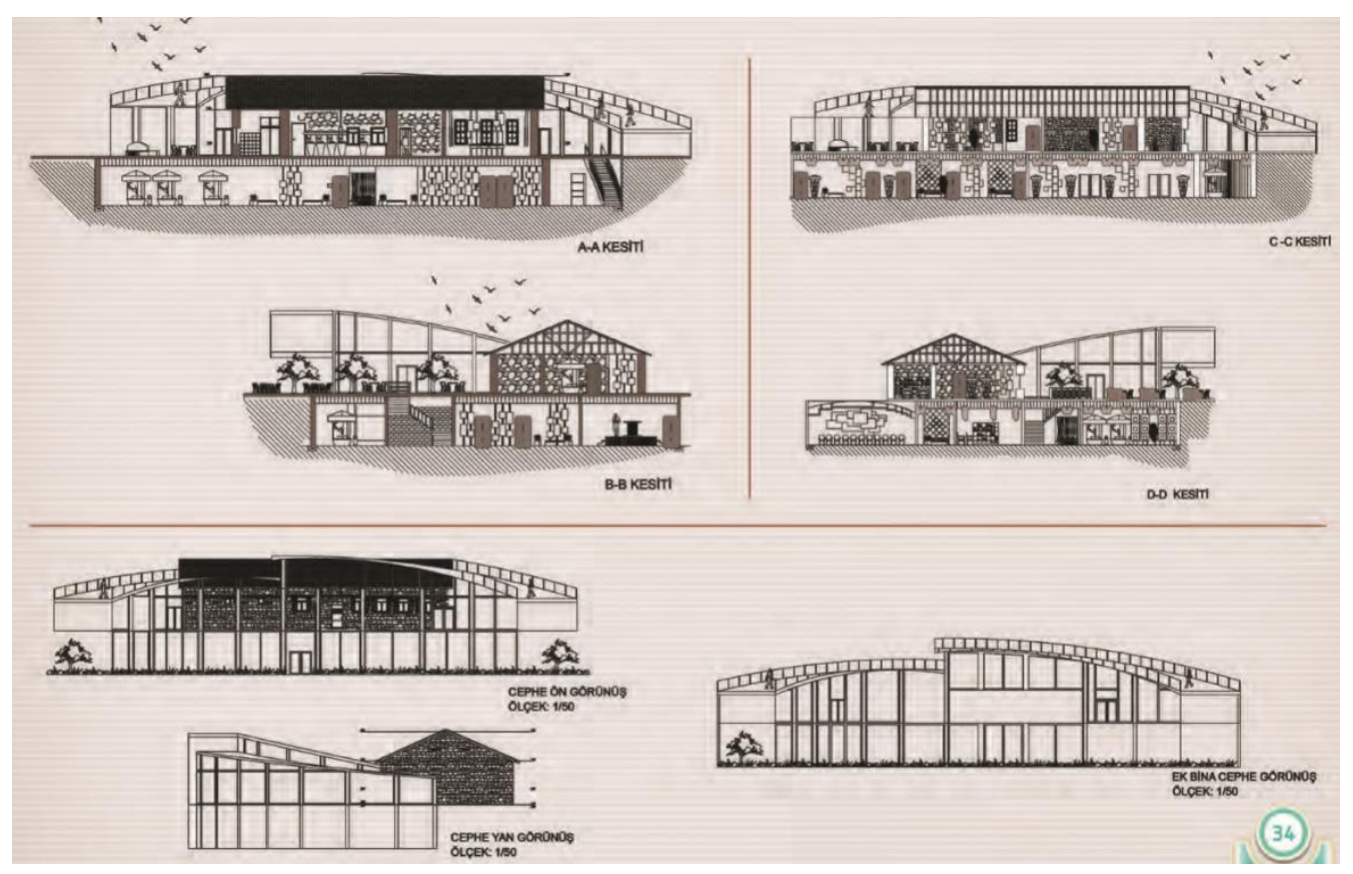

34. The project was designed by Burcu Küçük. 


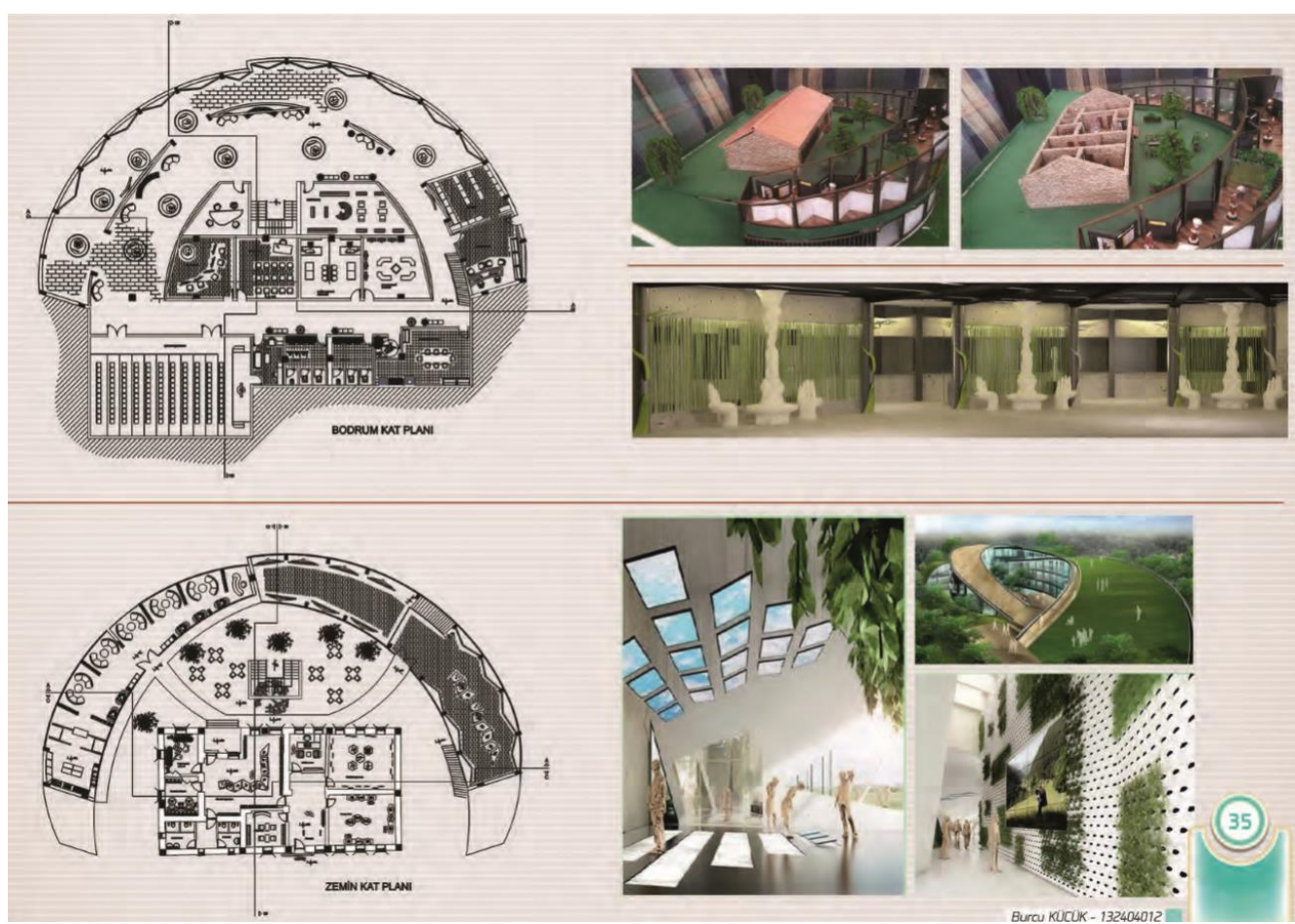

Figure 10. Sixth Design Work

\section{Seventh Design Work}

The main idea orienting the design process of the seventh design work ${ }^{35}$ is to use a local building material, wood, structurally for the construction of new additional building to provide harmony with the traditional buildings and contextual values (Figure 11). The new additions surrounding the historic building in two sides were constructed by laminated timber structures, covered with glass surfaces on top of it to provide transparency and not to disturb the visual perception of the historic building. Within the main building, there are specific spaces for exhibition on Botsa Village, workshops on weaving carpet and pottery and a café and entrance space, designed in open planning, within the new additional building covered with glass, including a sculptural stair going down to foyer on basement floor. On the basement floor constructed by carving, there are two workshops on contemporary arts, and a multi-purpose hall, a closed exhibition space and a large exhibition area connected to the foyer.

35. The project was designed by Tuğçe Özköse. 

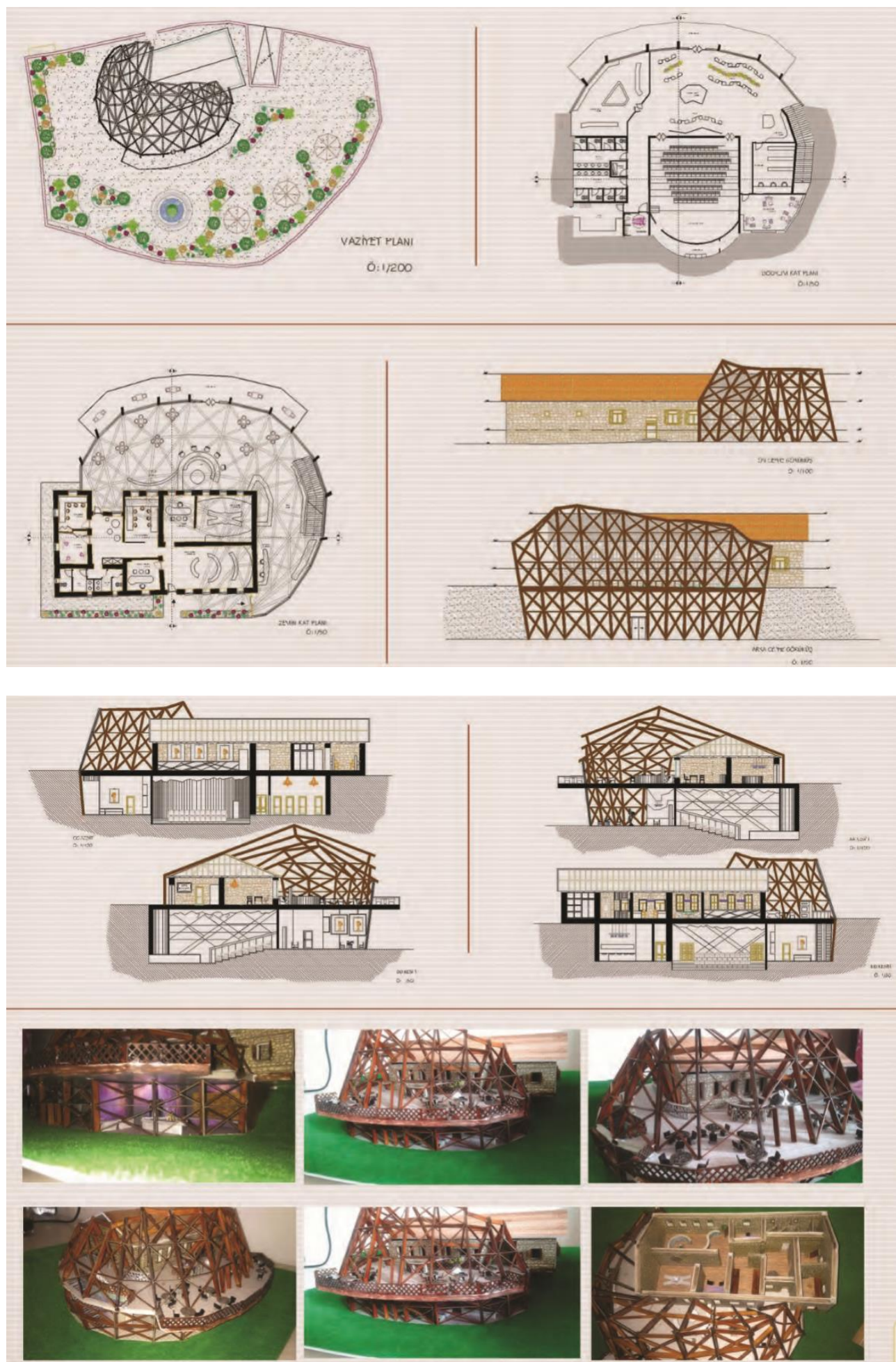

Figure 11. Seventh Design Work 


\section{Discussion and Conclusion}

The interdisciplinary studies on the conservation of cultural heritage carried out within the different departments of educational institutions provide to raise the consciousness of the students on both the intangible and tangible values of the historic buildings and environments. This study presented such an interdisciplinary studio project carried out in the department of interior architecture intending to increase the awareness of the students on both conservation of historic buildings and the ecological principles of traditional architecture. The interdisciplinary methodology of this studio work provided students learn thinking like as architects, folklorist and conservation architects to understand the intangible and tangible heritage elements of Botsa Village, the ecological principles of local architecture and the values of historic school buildings to be conserved.

The results of an interior design studio experience on village museum motivated students to understand and care the values of a historical settlement and building, raising awareness on their conservation besides discovering specific ecological principles in local traditional architecture. The common approach of the student projects was mainly based on designing a village museum trying to integrate local values and traditional living culture with the emerging new social, economic needs of villagers and to create employment in contemporary art activities. The projects were mostly common in exhibiting a great variety of the elements of cultural heritage of Botsa besides designing spaces for performing local crafts without any disruption of the originality and integrity of the historic building. Furthermore, the projects had a shared common strategy in using local building materials, like, wood and stone besides new materials; and designing a carved-out basement floor continuing local building culture within the modern architectural technology.

Taking a conceptual approach to interior design, and particularly the themes "village museum", "ecological architecture" and "adaptive reuse" was productive to the department of interior architecture's educational aims and processes. In addition, the selected theme could also be a focus for interdisciplinary study in the school's curriculum. Studying the elements of cultural heritage within a historic building provided students first to understand the elements of heritage, and its cultural context, and then, the building to provide the museum visitors virtual spatial experiences to percept and interact the intangible and tangible heritage of the village together.

\section{Bibliography}

Alivizatou, M. Museums and Intangible Heritage: The Dynamics of an "Unconventional" Relationship. London: UCL Institute of Archaeology, 2006, 17, 47-57.

Bahar, H. "Konya Araştırmaları III; Lykaonia| Konya Merkez Bölgesi." [Konya Researches III: Lykaonia.] Selçuk University Journal of Faculty of Letters (FenEdebiyat Fakültesi Edebiyat Dergisi) 12 (1998): 197-206.

Konya-Hatunsaray Yerleşmesinde Erken Demir Çağı Çanak Çömleği, Hatunsaray Yerleşmesi'nde Erken Demir Çağı'na Geçiş [Pottery of Early Iron Age in Konya- 
Hatunsaray Settlement | Transition to Early Iron Age in the Konya-Hatunsaray Settlement.] Institute of Turkish Ancient Age Sciences, 2003.

Bektaş, C. Koruma Onarım Conservation Restoration. İstanbul: Y.E.M. Yayın, 1992. Türk Evi [Turkish House.] İstanbul: Yapı Kredi Yayınları, 1996.

Bozkurt, T. "Konya-Hatunsaray (Lystra) ve Cevresindeki Cami ve Mescitler." [Mosques and Masjids nearby Environment of Konya-Hatunsaray (Lystra.)] Ankara Üniversitesi Dil ve Tarih-Coğrafya Fakültesi Dergisi 55, Jan. (2015): 1-54.

Dülgerler, O. N. and M. Sözen. Samples from Konya Houses [Konya Evlerinden Örnekler.] ODTÜ Mimarlık Fakültesi Dergisi, 1979, 5, 1.

Feilden, B. M. and J. Jokilehto. Management Guidelines for World Cultural Heritage Sites. Rome: ICCROM, 1993.

Feilden, B. Conservation of Historic Buildings. London; Boston: Butterworth Scientific, 2003.

Icomos New Zealand. Charter for the Conservation of Places of Cultural Heritage Value. 2010. https://bit.ly/2LqJNBa.

Karakul, Ö. "Designing the Museum of Turkey's Intangible Cultural Heritage: A Studio Experience of Interior Architectural Design." Milli Folklor-International and Quarterly Journal of Cultural Studies 30, no. 120 (2018): 140-157. . Discovering Ecological Principles of Traditional Architecture: Cappadocia Region. Sustainable Housing 2016-International Conference on Sustainable Housing Planning, Management and Usability, 16-18 November. Porto, Portekiz, 2016. . "Bozkırda Yeşeren Köy| Botsa." [A Greening Village Over Steppe | Botsa.] Yapı Dergisi, Yapı Endüstri Merkezi 433 (2017): 154-158.

Karpuz, H. Osmanlı'da Konut Mimarisi Konya Örneği [Ottoman Dwelling Architecture: Case of Konya.] İstanbul: Eyüp Sultan Sempozyumu III, 2000.

."Konya'da Halk Mimarisi." [Folk Architecture in Konya.] Erdem 38, no. 10 (2002).

Kortan, E. Le Corbusier Gözüy le Türk Mimarlık ve Sehirciligi [Turkish Architecture and Urbanism from the Point of View of Le Corbusier.] Ankara: ORTA DOĞU TEKNIK ÜNIVERSITESİ, 1983.

Kuban, D. Tarihi Çevre Korumanın Mimarlık Boyutu: Kuram Ve Uygulama [Architectural Dimension of Historic Environment Conservation: Theory and Practice.] İstanbul: Yap1-Endüstri Merkezi Yayınları, 2000.

Madran, E. and N. Özgönül. Kültürel ve Doğal Değerlerin Korunması [Conservation of Cultural and Natural Values Ankara.] Mimarlar Odas1, 2005.

Mimiroğlu, İ. M. Kilistra-Gökyurt, Meram Municipality. Konya, 2014.

Stefano, M. L. "Safeguarding Intangible Heritage: Five Key Obstacles Facing Museums of the North East of England." International Journal of Intangible Heritage 4, Jan. (2009): 111-26.

Unesco. The Roles of Museums in Safeguarding Intangible Cultural Heritage. UNESCO Convention, October 2003. Position Paper for the Expert Meeting, 2004.

Unesco. The Convention for the Safeguarding of the Intangible Cultural Heritage, October 2003. Paris.

Weber, W. and S. Yannas (eds.) Lessons from Vernacular Architecture. Great Britain: Routledge, 2014.

Zakar, L. and K. K. Eyüpgiller. Mimari Restorasyon Koruma Teknik ve Yöntemleri [Conservation Techniques and Methods of Architectural Restoration.] İstanbul: Ömür Matbaacılık, 2015. 
